\title{
DISTANCED BY DEFAULT OR THE MANDATES OF MARGINALIZATION IN CAMUS'L'ÉTRANGER
}

Mary Jo Muratore*

7 he enigmatic Meursault has preoccupied readers for over a half a century, and there is little danger that critics will exhaust any time soon the interpretive possibilities Camus' narrative provides. Because of Camus' pivotal role in the existentialist movement, L'Étranger is often read as a kind of philosophical bildingsroman wherein the protagonist moves from a state of selfindulgent unawareness to metaphysical lucidity as a result of his experiences. In such readings, Meursault's detached egocentrism, so prominently in evidence in Part 1, is supplanted by his discovery of an indifferent universe in Part 2. The problem with this reading is that it suggests Meursault undergoes a fundamental intellectual shift when in truth he simply confirms what he already suspected (“J'avais eu raison, j'avais encore raison, j'avais toujours raison" [p. 1208]). ${ }^{1}$

One of Meursault's metaphysical certainties is that the inevitability of death nullifies any sense of purpose in life, making it hardly worth living at all ("Mais tout le monde sait que la vie ne vaut pas la peine d'être vécue" [p. 1204]).

* University of Missouri - Columbia

1 All references are to: CAMUS, A. Théâtre, Récits, Nouvelles. Paris: Pléiade, 1962; CHATAIN, G. D. Narrative Desire. In: KING, A. L'Étranger, Camus's L'Étranger: Fifty Years On. New York: St. Martin's Press, 1992. p. 127, also notes the deficiencies of an evolutionary reading due to Meursault's reluctance to seriously consider his crime. 
But this rather banal observation from a condemned man provides scant evidence of a metaphysical transformation. Indeed, its very lack of sophistication underscores the fact that neither Meursault nor his thought can be said to have evolved much within the novel. Meursault's fundamental intellectual perspective and his situational reality remain fairly static from beginning to end. We first see him within the prison-like setting of the home wherein death stalks the residents within, and we last see him on death row, awaiting his own execution. His dispassionate impartiality, his preoccupation with sensual gratification, his ineloquent and depersonalized narrative manner appear unaltered. Meursault in prison is very much the same character we saw at his mother's funeral. ${ }^{2} \mathrm{He}$ remains almost pathologically observant:

Malgré la chaleur (j'étais en manches de chemise), il avait un costume sombre, un col cassé et une cravate bizarre à grosses raies noires et blanches (1170);

considerate of others:

J'ai trouvé qu'il était très commode que la justice se chargeât de ces détails. Je le lui ai dit (p.1169);

brutally honest:

Il m'a demandé s'il pouvait dire que ce jour-là j'avais dominé mes sentiments naturels. Je lui ai dit: 'Non, parce que c'est faux"(p. 1170);

Jai réfléchi et j'ai dit que, plutôt que du regret véritable, j'éprouvais un certain ennui (p. 1174);

2 Richard-Laurent Barnett's compelling analysis of Camus' text (cf. BARNETT, R-L. Le simulacre inaugural: micro-lecture camusienne. Symposium, ano 2, n. 53, p. 59-69, 1999) underscores the very essence of non-evolution - metaphysically and structurally. The narrative, he persuasively demonstrates, is borne of, and sustained, by unremitting sameness: "Car la suite découlera justement du paradigme initial. (...) Le texte constitue, en fin de compte, une inépuisable reprise - implicite, ludique, parfois insidieuse - du même et seul commencement" (p. 64). A problematic otherly formulated in Barnett's insightful decoding of La Peste, wherein the textual weave "leads the reader from the semiotic casting of nothingness through a horror story of putrescence and pain, only to return him once again, and all the more tragically, to the state of implacable absence whence the drama was born. The narration's birth and death are undifferentiated, undifferent, in fact, equivalencies at opposite ends of a time lapse..." (Cf. BARNETT, R-L. The Trope Disfigured: Effacement and Epidemicity in Camus' La Peste. Rivista di Letterature moderne e comparate, ano 3, n. 54, p. 309, 2001). See also, Gilbert Chatain (1992, p. 133). 
frustratingly un-engaged:

Au début, je ne l'ai pas pris au sérieux (p. 1169);

J'allais lui dire qu'il avait tort de s'obstiner: ce dernier point n'avait pas tellement d'importance (p. 1173);

Et même, dans un sens, cela m'intéressait de voir un process. Je n'en avais jamais eu l'occasion dans ma vie (p. 1182).

More importantly, he maintains throughout his defiance of authority. When the chaplain enters his cell hoping to extract the conventional mea culpa from the repentant captive, Meursault very nearly strangles him.

If Meursault does not evolve, then we are obliged to conclude that he is an "étranger" from the outset, an observation that the textual evidence simply does not support. How then, does Meursault move from anonymous civil servant to social pariah? His evolution, I argue, is not internal, but external. In L'Étranger, evolution of character takes place in the eyes or in the attitude of others. In the case of Meursault, he is both the subject and object of the victimization process. As such, the novel offers a window into the means and motivations underpinning the socially bred impulse to demonize the vulnerable, that is to say, to assume as one's own the hatreds and prejudices of one's social network. ${ }^{3}$ L'Étranger investigates how the need to belong can persuade even those for whom impartiality constitutes their most cherished value, individuals such as Meursault and the judges, to transform benign indifference into a chorus of malevolent contempt. ${ }^{4}$ In Camus' novel, the almost primal need to align oneself with a groundswell of conviction extorts the moral capitulation of both the fair-minded and the prejudiced. What is interesting in this work, however, is not simply the

3 The convulsive and destructive effects of blind, pervasive conformism which ultimately find their fullest expression in Ionesco's Rhinocéros are in a sense preemptively encoded here, in compelling through nascent form. A related analysis linking Meursault to the conventional scapegoat figure is explored in Nina Sjursen's Girardien reading of L'Étranger where the hero functions as the designated scapegoat intended to re-order a fragmenting society. See her article "Meursault, Un Job de Notre Temps? Une Lecture Girardienne" (Revue des Lettres Modernes, n. 16, p. 123-135, 1995). See also Robert Champigny's references to Meursault's demonization in Sur un héros païen (Paris: Gallimard, 1959. p. 127-130).

4 MOROT-SIR, É. Actualité de L'Etranger. Revue des Lettres Modernes, n. 17, p. 12, 1996; also suggests that L'Étranger offers a condemnation of the pressure of collective opinion. 
role public opinion plays in individual judgments, but how readers are called upon not only to watch, but actually participate in, the process of Merusault's demonization.

Although most readers interpret the title as a commentary on Meursault's behavioral unconventionality, our initial impression of him as an "outsider" relates primarily to his status as a "foreign" presence in the retirement home at Marengo. The home is geographically displaced from the narrative center, making Meursault a foreigner in the most fundamental sense of the term. Additionally, his relative youth contrasts sharply with the grotesque tatters of human beings he is obliged to confront. Adding to his alienated status is Meursault's fundamental ignorance of the home's prevailing customs ("Jai voulu voir maman tout de suite. Mais le concierge m'a dit qu'il fallait que je rencontre le directeur" [p. 1126]). All the routine protocols must be painstakingly explained to him, and the elderly residents view this unfamiliar intruder with unveiled suspicion ("Ils se taisaient quand nous passions. Et derrière nous, les conversations reprenaient" [p. 1127]). In fact, everything in the home appears deformed, unfamiliar. The nurse in charge is disfigured by disease, and her jerky movements are but a source of conjecture for the mystified Meursault ("Je ne voyais pas ce qu'elle faisait. Mais au mouvement de ses bras, je pouvais croire qu'elle tricotait" [p. 1129]). The sense of alienation is accentuated further by Meursault's inability to understand the language of the residents ("On aurait dit d'un jacassement assourdi de perruches" [p. 1127]) or even if the peculiar sounds they make are an attempt to communicate at all:

De temps en temps seulement, j'entendais un bruit singulier et je ne pouvais comprendre ce qu'il était. A la longue, j'ai fini par deviner que quelques-uns d'entre les vieillards suçaient l'intérieur de leurs joues et laissaient échapper ces clappements bizarres. (p. 1130)

Although the residents of the home seem to view Meursault as the outsider in their midst, it is the elderly, seen through the eyes of Meursault, who are expressly drawn to appear grotesque, even inhuman ("Pourtant je ne les entendais pas et j'avais peine à croire à leur réalité" [p. 1129]). The alien portraits offered by Meursault are intended to convey a sense of revulsion, even a kind of desanctification of these parental remnants. Meursault's descriptive accounts 
are brutal, devoid of any sympathetic nuances that might logically attach to these pathetic human beings guilty of no other crime than aging:

Presque toutes les femmes portaient un tablier et le cordon qui les serrait à la taille faisait encore ressortir leur ventre bombé. Je n'avais encore jamais remarqué à quel point les vieilles femmes pouvaient avoir du ventre. Les hommes étaient presque tous très maigres et tenaient des cannes. Ce qui me frappait dans leurs visages, c'est que ne je ne voyais pas leurs yeux, mais seulement une lueur sans éclat au milieu d'un nid de rides. Lorsqu'ils se sont assis, la plupart m'ont regardé et ont hoché la tête avec gêne, les lèvres toutes mangées par leur bouche sans dents, sans que je puisse savoir s'ils me saluaient ou s'il s'agissait d'un tic. (p. 1129).

Ses lèvres tremblaient au-dessous d'un nez truffé de points noirs. Ses cheveux blancs assez fins laissaient passer de curieurses oreilles ballantes et mal ourlées dont la couleur rouge sang dans ce visage blafard me frappa. (p. 1133)

Additionally, the home is made to resemble a prison, foreshadowing the link between social alienation and culpability that constitutes a fundamental theme of this work. The elderly at Marengo appear as involuntary detainees, either as some kind of punishment for having grown old, or from the need to shield the public from their discomforting deformities. The soldier seated by Meursault on the bus introduces the notion of forced internment ("Et quand je me suis réveillé, j'étais tassé contre un militaire qui m'a souri et qui m'a demandé si je venais de loin" [p. 1126]), an initial impression that is borne out by the reality within. A grim combination of suspicion, fear and discomfort hangs over the home wherein the elderly often appear to be the vulnerable victims of sadistic and controlling administrators who program, monitor and control routine behaviors. Rituals at the home allow for no variation or exemption; every move is scripted with chronological exactitude. Compliance with established protocols is enforced regardless of an individual resident's preferences on the matter. For example, inmates are permitted to attend the wake, but not the burial. Thomas Pérez, however, has been granted special permission to attend the burial and is 
therefore barred from keeping vigil over the body. Meursault's mother is given a church burial, even though she was not a religious woman ("Maman, sans être athée, n'avait jamais pense de son vivant à la religon"). Visitors, too, are subjected to the same regimented constraints. Meursault's request that the bright lights be dimmed is summarily dismissed without apology:

Je lui ai demandé si on pouvait éteindre une des lampes. L'éclat de la lumière sur le murs blancs me fatiguait. $\mathrm{Il} \mathrm{m}$ 'a dit que ce n'était pas possible (p. 1129)

Contributing also to the prison-like nature of the home are its punishing rituals. Often, the conditions under which the residents and visitors are obliged to operate seem expressly designed to inflict pain, such as the grueling vigil over the body("j'étais fatigué et les reins me faisaient mal" [p. 1130]) and the arduous march to the distant graveside ("L'éclat du ciel était insoutenable" [p. 1134]). Small wonder that Meursault is eager to leave the home as quickly as feasible.

Back in Algiers, Meursault resumes easily his normal routine. Aside from a few relatively minor eccentricities, the unremarkable Meursault seems hardly worthy of the title imposed upon him. ${ }^{5}$ In fact, the unassuming Meursault seems an unlikely candidate for distinctiveness of any kind. Passions and principles are ephemeral concepts to this anti-hero who lives life in the most minor of keys. Empathetic and sensitive, he is loathe to offend others and is therefore quick to acknowledge the validity of opposing viewpoints. Meursault is notably careful to avoid articulating extreme views of any sort, not unlike the honnête homme in salon society. Meursault is committed to living as frictionless an existence as possible and appears fundamentally programmed to please (“J'aurais voulu le retenir, lui expliquer que je désirais sa sympathie, non pour être mieux défendu, mais, si je puis dire, naturellement," [p. 1171]). Even his sensual desires tend towards the mundane and the unspectacular: an occasional café au lait or bottle of wine; dry hand towels at work; intimacy with pretty women; a refreshing swim in the ocean. He reveals no spectacular talents, no flamboyance of personality, no conversational brilliance, nothing that might serve to particularize him from anyone else.

5 See also CHAMPIGNY, 1959, p. 15-24. 
It bears noting also that he is well liked by his co-workers and neighbors, and he makes a good impression on those who meet him for the first time, an indication that he has excellent social skills. Masson and his wife, for example, take an immediate liking to him, as do most all the other characters in the novel. In fact, virtually everyone finds Meursault to be charming, and pleasant to be around. Even the juge d'instruction who initially decries his atheism is subsequently drawn to him ("le juge me reconduisait à la porte de son cabinet en me frappant sur l'épaule et en me disant d'un air cordial: "C'est fini pour aujorud'hui, monsieur l'Antéchrist" [p. 1174]). In prison as well, he quickly earns the sympathy of fellow Arab inmates, and even the gardien-chef.

Meursault's most, if not his only, distinctive characteristic is his pathological impartiality, his unwillingness to condemn, or even to judge others. A man of few words and fewer convictions, Meursault prefers to observe the world from the safe distance of his balcony rather than engage it directly. ${ }^{6}$ In striking contrast to his opinionated, occasionally prejudiced, counterparts, Meursault is reluctant to accept even the safest assumptions of conventional wisdom. More moralist than moralizer, he is alone in refusing to condemn Salamano for beating his dog (“Céleste dit toujours que 'c'est malheureux', mais au fond, personne ne peut savoir" [p. 1142]); he fraternizes openly with his neighbor Raymond who is reputed to be a pimp ("Je trouve que ce qu'il dit est intéressant. Dailleurs, je n'ai aucune raison de ne pas lui parler" [p. 1143]). Likewise, Meursault refutes the generalized assumption that Paris is in any way preferable to Algiers (“C'est sale. Il y a des pigeons et des cours noires. Les gens ont la peau blanche" [p. 1154]). He will not even articulate the conventional emotional clichés that serve to "legitimize" (conventionalize) sexual relationships. Meursault seems in fact to support indiscriminately the cause of everyone he meets, refusing to privilege one position or one person over any other, even on the emotional plane:

Elle voulait simplement savoir si j'aurais accepté la même proposition venant d'une autre femme, à qui je serais attaché de la même façon. J'ai dit: "Naturellement". (p. 1154).

6 It is his detachment which condemns him, notes BARTFELD, F. Aspects du destin dans L'Étranger. Hebrew University Studies in Literature \& the Arts, ano 2, n. 9, p. 311, 1981 - "Et qui dit détachement dit souvent antipathie. En sorte que le lecteur ressent déjà comme condamnables beaucoup de signes étonnants du comportement de Meursault. Le lecteur est 'en avance' sur le heros". 
Meursault's narrative manner, like the man himself, is a rather drab conglomeration of impersonal nuances. The hero is not one to dominate by the frantic force of rhetoric. On the contrary, he offers no rhetorical enigmas to disentangle, no elliptical pronouncements to interpret. He is, in fact, so obsessed with narrative precision that he often corrects his own initial observations:

J'avais même l'impression que cette morte, couchée au milieu d'eux, ne signifiait rien à leurs yeux. Mais je crois maintenant que c'était une impression fausse. (p. 1130)

J'ai eu l'impession que Raymond savait où il allait, mais c'était sans doute faux. (p. 1163)

Compared to the persuasive and motivated rhetoric of the defense counsel and chaplain, Meursault's discourse appears diluted and tentative. It is not, in other words, a discourse capable of defending a position or making a persuasive argument, goals which are foreign to him in any case.

Meursault's non-partisan nature is itself a distinguishing feature in a narrative context wherein evaluative opinions are everywhere in evidence. All in the novel are subject to some sort of evaluative process. For example, the welldressed man that Meursault observes from his balcony is more favorably considered than his dowdy wife ("En le voyant avec sa femme, j'ai compris pouquoi dans le quartier on disait de lui qu'il était distingué" [p. 1138]). Salamano is widely criticized for beating his dog. Raymond is rumored to be a pimp ("Dans le quartier, on dit qu'il vit des femmes" [p. 1143]). Even Meursault is the victim of opinionated commentary. According to Salamano, the neighborhood was quite critical of his decision to send his mother to a home ("Il m'a dit alors, très vite,et avec un air gêné, qu'il savait que dans le quartier on m'avait mal jugé parce que j'avais mis ma mère à l'asile" [p. 1157]).

In such a judgmental arena, it is not surprising to discover that most characters in the novel worry about the impression they are making on others. At the home, the concierge is quick to underscore his apartness from the others, to point out to Meursault his "elevated" status: 
Dans la petite morgue, il m'a appris qu'il était entré à l'asile comme indigent. Comme il se sentait valide, il s'était propose pour cettte place de concierge. Je lui ai fait remarquer qu'en somme il était un pensionnaire. Il m'a dit que non. (p. 1128)

Raymond, too, is eager to protect his tough-guy image and worries that Meursault's opinion of him will be diminished when he is humiliated by the policeman :

Il m' a demandé alors si javais attendu qu'il réponde à la gifle de l'agent. J'ai répondu que je n'attendais rien du tout et que d'ailleurs je n'aimais pas les agents. Raymond a eu l'air très content. (p. 1150).

Meursault also betrays a strong desire to please, and like everyone else, is concerned about his image and the manner in which his actions are perceived. $\mathrm{He}$ is particularly eager to be reviewed favorably by his boss. He makes a practice of being punctual ("Il était tard et j' ai couru pour attraper un tram" [p. 1142]) and he even hesitates to ask for time off from work to attend his mother's funeral ("J'ai demandé deux jours de congé à mon patron et il ne pouvait pas me les refuser avec une excuse pareille. Mais il n'avait pas l'air content" [p. 1125]). He is also loathe to accept personal calls at work for fear of displeasing his boss ("J'ai voulu raccrocher tout de suite parce que je sais que le patron n'aime pas qu'on nous téléphone de la ville" [p. 1153]). When his lack of enthusiasm for a promotion angers his boss, Camus regrets having jeopardized his employee standing ("J'aurais préferé ne pas le mécontenter, mais je ne voyais pas de raison pour changer ma vie" [p. 1154]). For a man eager to please, all these negative assessments are troubling, and we have a better understanding of why he was so discomfited at the home. The intense scrutiny of the elders and staff at Marengo led him to fear that he making a poor impression: ${ }^{7}$

7 Vincent Grégoire makes an interesting observation when he notes that Meursault feels guilty about committing minor behavioral transgressions, but expresses no remorse for actually killing a man. See his remarks in Monde "sourd"-Monde "absurde" ou Pour une impossibilité de s'entendre dans L'Étranger (Romanic Review, ano 3, n. 85, p. 413, 1994): 
MURATORE, M. J. Distanced by default or the mandates...

J'ai cru qu'il me reprochait quelque chose et j'ai commencé à lui expliquer (1126).

Il s'est interrompu et j'étais gêné parce que je sentais que je n'aurais pas dû die cela. (p. 1127)

Je ne sais pas quel geste j'ai fait, mais il est resté debout derrière moi. Cette présence dans mon dos me gênait. (p. 1128)

J'ai eu un moment l'impression ridicule qu'ils étaient là pour me juger. (p. 1130)

Meursault's desire to please others, to fit in with his peers, causes him to prize resemblance over distinctiveness. In a society where one's social context can be determined by visual indicators, resemblance constitutes the outward sign of one's inclusiveness. Straw hats, bow-ties, and dapper clothing convey signs of good breeding and a high social status. Social groups can be recognized by conventional manner of dress and behavior. The popular young men in the neighborhood all sport similar hair and clothing styles ("Un peu plus tard passèrent les jeunes gens du faubourg, cheveux laqués et cravate rouge, le veston très cintré, avec une pochette brodée et des souliers à bouts carrés [ $\mathrm{p}$. 1138); the young girls share similar gaits and gestures ("Les jeunes fills du quartier, en cheveux, se tenaient par le bras [p. 1139]). Members of the town's athletic team can be identified by their suitcases ("Les tramways suivants ont ramené les joueurs que j'ai reconnus à leurs petites valises" [p. 1139]).

Meursault, too, expresses the desire to be seen as just an ordinary man, indistinguishable from those with whom he regularly interacts:

J'avais le désir de lui affirmer que j'étais comme tout le monde, absolument comme tout le monde (1171).

"Le héros se sent ainsi paradoxalement coupable pour des actions bénignes, dans la première partie de l'histoire; cependant que, dans la deuxième partie, il va déclarer qu'il n'a ni regrets ni remords en ce qui concerne la mort de l'Arabe mais seulement de l'ennui'. 
Sans transition, il m'a demandé si j'aimais maman J'ai dit: “Oui, comme tout le monde"... (1172)

This desire to belong, to resemble his peers, is evident in his tendency to replicate the gestures of those around him. Shortly after Meursault returns home from his mother's funeral, we see him alter his sitting posture to mimic that of the tocabacconist (“J'ai retourné ma chaise et je l'ai placée comme celle du marchand de tabac" [p. 1138]). Later, he confirms his desire to enter into a relationship with a former office secretary when he follows her lead by climbing on and off a raft while swimming ("Je me suis hissé à côté d'elle sur la bouée" [p. 1136-1137]; "Quand le soleil est devenu trop fort, elle a plongé et je lai suivie" [p. 1137]). As the liaison progresses, Meursault continues to pattern his actions after hers ("Marie m'a appris un jeu. Il fallait, en nageant, boire à la crête des vagues, accumuler dans sa bouce toute l'écume et se mettre ensuite sur le dos pour la projeter contre le ciel" [p. 1148]). Similarly, his allegiance to Raymond is confirmed when he assumes the latter's identity by writing a letter expressing his neighbor's sentiments.

This mimetic instinct counters, and eventually almost destroys, Meursault's characteristic ambivalence, his one distinctive trait. Whereas his early encounters with Raymond are characterized by passive ambivalence ("Je n'ai rien dit et il m'a demandé encore si je voulais être son copain. J'ai dit que ça m'était égal; il a eu l'air content" [p. 1144]), this ambivalence shades slowly, but perceptively into unanticipated partisanship ('Il m'a demandé si je pensais qu'il y avait de la tromperie, et moi, il me semblait bien qu'il y avait de la tromperie, si je trouvais qu'on devait la punir et ce que je ferias à sa place, je lui ai dit qu'on ne pouvait jamais savoir, mais je comprenais qu'il veuille la punir [p. 1145]). Partisanship then slides almost effortlessly into advocacy. Meursault makes no effort to call the police when cries from Raymond's battered mistress can be heard coming from his apartment, and he then agrees to act as Raymond's character witness at the police station ("Jai accepté de lui servir de témoin" [p. 1150]). The ease with which Meursault's heralded ambivalence evolves into active complicity offers a chilling confirmation of Marie's earlier observations regarding the inconstancy of conviction ("Après un autre moment de silence, elle a murmuré que j' étais bizarre, qu'elle m'aimait sans doute à cause de cela mais que peut-être un jour je la dégoûterais pour les mêmes raisons" [p. 1154]). Here Meursault offers an excellent case in point. Despite his commitment to impartiality and evenhandedness, in exchange for one or two bottles of wine 
MURATORE, M. J. Distanced by default or the mandates...

and some black pudding, he is easily persuaded to side with Raymond rather than his mistress.

A grateful Raymond later invites Meursault to spend the day at a friend's beach house. The episode with Raymond, Marie and Meursault at the beach constitutes a palpable turning point in the novel. This section contains some of the most poetic passages in the novel, and it is the moment when Meursault appears the most natural, the most well-adjusted, the most contented. ${ }^{8}$ The multiplicity of sensual pleasures at the beach (intimacy with Marie, refreshing swims, copious wine, culinary gratification) seems to have a positive effect on Meursault, who for the first time seriously considers marrying Marie ("Pour la première fois peut-être, $j$ 'ai pensé vraiment que j'allais me marier” [p. 1160]). He even makes tentative plans to spend the entire summer at the beach with his new friends ("Masson, Raymond et moi, nous avons envisage de passer ensemble le mois d'août à la plage, a frais communs" [p. 1161]).

Meursault's clearly altered viewpoint, while engaging, is also troubling because it demonstrates how quickly allegiance to personal principles can fade when they come into conflict with the priorities, or even the prejudices, of one's social network. The more socially entrenched Meursault becomes, the more persuaded he is to adopt the perspectives of his peers. His transformation from an independent-thinking individualist to conforming automaton is most evident during the violent encounter on the beach. When Raymond, Masson and Meursault meet up with Raymond's Arab adversaries, the two long-standing friends (Raymond and Masson) accept Meursault as one of their own, and he is assigned a role in their battle for territorial supremacy. Meursault is to act as the group's look-out, and if needed, take on any additional adversaries should they appear. Meursault's eager compliance with Raymond's directives demonstrates how strong his desire to be a contributing member of the group, to fulfill his somewhat marginalized, but critical role. During the fight, he does notice that one of the Arabs is armed, and calls out a warning. He is too late, however. Unfortunately, Raymond is already wounded. Meursault has therefore failed his first test in the group initiation process.

In the aftermath of the assault, Meursault finds himself isolated once again. The wounding has the effect of fracturing the intense feelings of fraternal bonding in evidence during the encounter between the two adversarial teams.

8 Notes MISTACCO, V. Mama's Boy: Reading Woman. In: KING, A. (Ed.). L'Étranger. Camus's L'Étranger: Fifty Years On. New York: St. Martin's Press, 1992. p. 163 ; in the scene at the beach, Meursault becomes more normal, that is to say, he conforms to expected gender roles. 
Masson and Raymond go for medical attention, leaving Meursault behind with the women (an emasculation), and feeling abandoned:

Il est parti avec Masson et je suis resté pour expliquer aux femmes ce qui était arrivé. Mme Masson pleurait et Marie était très pâle. Moi, cela m'ennuyait de leur expliquer. J'ai fini par me taire et j'a fumé en regardant la mer. (p. 1163)

Further evidence of fraternal unraveling can be seen in Raymond's hostile attitude upon his return. Perhaps intent on revenge, Raymond heads back to the beach, angrily rejecting his friends' offer to accompany him ("Masson et moi avons dit que nous allions l'accompagner. Alors, il s'est mis en colère et nous a insultés" [p. 1163]). Not yet ready to accept ostracism, Meursault follows. When they meet up with the Arabs a second time, Meursault's use of the first person plural reveals that Meursault has assumed part of Raymond's identity in that he views his friend's enemies as his own ("Là, nous avons trouvé nos deux Arabes" [p. 1163]). ${ }^{9}$ The opportunity for a redemptive second battle and renewed social bonding presents itself, but it soon becomes evident that the moment of solidarity has passed. There is no longer a definite consensus of opinion, no cohesive commitment to a plan of action. Raymond, the group leader, has lost his sense of conviction. Rather than bark orders as he did during the initial encounter ("S'il y a de la bagarre, toi, Masson, tu prendras le deuxième. Moi, je me charge de mon type. Toi, Meursault, s'il en arrive un autre, il est pour toi" [1162]), he is here uncertain. He no longer commands, but seems ready to follow, asking Meursault for advice ("Je le descends?" [p. 1164]). During this second encounter, there are not three minds acting as one, but rather two separate entities making separate determinations on the basis of isolated perspectives. Freed from the hypnotic power of group consensus, Meursault's characteristic ambivalence returns ('J'ai pensé à ce moment qu'on pouvait tirer ou ne pas tirer"[p. 1164]). Meursault now dissuades Raymond from killing his adversary.

When the men return to the beach house, Meursault begins to revert to type. He cannot decide whether to join his friends in the cabin, or abandon them

9 See also, MISTACCO (1992, p. 163); BROCK, R. Meursault the Straw Man. Studies in the Novel, n. 25, ano 1, p. 94, 1993; also takes note of the passage's more poetic nature. 
MURATORE, M. J. Distanced by default or the mandates...

entirely. The social outing on the beach has demonstrated that social commitments always entail a concomitant loss of individuality, and Meursault seems uncertain as to whether or not the rewards of comraderie compensate for the loss of selfmastery:

Je l'ai accompagné jusqu'au cabanon et, pendant qu'il gravissait l'escalier de bois, je suis resté devant la première marche, la tête retentissante de soleil, découragé devant l'effort qu'il fallait faire pour monter l'étage de bois et aborder encore les femmes. Mais la chaleur était telle qu'il m'était pénible aussi de rester immobile sous la pluie aveuglante qui tombait du ciel. Rester ici ou partir, cela revenait au même. (p. 1164)

This ambivalence is characteristic of the earlier Meursault, the detached, impartial colleague and neighbor who preferred observation to engagement. Meursault decides finally to leave the facile comfort of his newly formed social network, and heads away from the cabin, back towards the beach. Determined to regain his lost identity, he moves determinedly back towards isolation. His decision to liberate himself from the group proves more difficult than anticipated, however. Every step away from the cabin requires effort, and the journey is fraught with images recalling the memory of combat partnership and his failed role in the struggle. "Cétait le même éclatement rouge" (p. 1165), he notices, in other words, the same hot son that presided over the original encounter of intense bonding, when Meursault complained of being "à moitié endormi par ce soleil" (p. 1162). As he progresses along the beach, flashes of light teasingly recall the glistening knife he tried to caution against ("A chaque épée de lumière jaillie du sable, d'un coquillage blanchi ou d'un débris de verre, mes mâchoires se crispaient" [p. 1165]). He continues to forge ahead, however, and he is almost free ("J'avais envie de retrouver le murmure de son eau, envie de fuir le soleil, l'effort et les pleurs de femme, envie enfin de retrouver l'ombre et son repos" [p. p. 1165]) when Raymond's Arab enemy suddenly re-appears. The combination of light, heat, fear and anticipation weaken Meursault's defenses and compromise his quest for independence. "Cétait le même soleil, la même lumière sur le même sable qui se prolongeait ici” (p. 1165), he notes again, as if the sun were a call to arms, as if nature itself were conspiring against his attempt to regain mastery over his identity. Meursault tries to resist, tries to distance himself from a man 
who is essentially Raymond's enemy not his. Desperate to reach the shadows of self-exile, he wants only to move beyond this last remaining obstacle. The sun now fuses images of his mother's burial with memories of the fight on the beach and Meursault believes the Arab to be mocking him ("Peut-être à cause des ombres sur son visage, il avait l'air de rire" [p. 1166]). The recollection of his mother's burial conjures up painful images of his earlier outsider status, another occasion during which an awkward Meursault seemed to be on the unfavorable side of a critical jury. Some inexplicable force, the innate desire to belong or to dominate, perhaps, drives him forward. The Arab reacts to Meursault's aggression by drawing his knife. The sun's rays against the blade release a flash of light that transposes Meursault back in time, to the mystical ecstasy of collective violence and his failed role in his group's performance:

La lumière a giclé sur l'acier et c'était comme une longue lame étincelante qui m'atteignait au front. Au même instant, la sueur amassée dans mes sourcils a coulé d'un coup sur les paupières et les a recovertes d'un voile tiède et épais. (p. 1166)

He will not fail the group a second time. As Meursault surrenders to his desire for social approval, the trigger gives way. In a disassociative fugue of misguided group loyalty, Meursault kills a man with whom he had no individual quarrel. Immediately after the fatal shot, Meursault acknowledges his moral defeat. The surrender to the impulse of collective loyalty has eviscerated his quest for independence..$^{10}$ In proper existentialist fashion, Meursault refuses to allow his last significant action to be a gesture of capitulation to another's will. Rather than allow group mysticism to triumph over individual conviction, he fires four deliberate shots into the corpse of the Arab. In so doing, Meursault can attempt to take responsibility for his fate, though the gesture will remain largely symbolic. ${ }^{11}$

On trial for the murder, Meursault's outsider status is formalized, reminiscent of his situation at the home in Marengo. He faces those who judge

10 Notes RIGGS, L.; WILLOQUET-MARICONDI, P. Colonialism, Enlightenment, Castration: Writing, Narration, and Legibility in L'Étranger. Studies in Twentieth Century Literature, ano 2, n. 16, p. 267, 1992. Meursault becomes the conduit for another's desire and hatred. 
him, he is subject to ritualistic protocols (including not being permitted to speak on his own behalf), he is in some sense almost accessory to the proceedings ("Je me suis expliqué aussi la bizarre impression que j' avais d'être de trop, un peu comme un intrus" [p. 1183]). In fact, he is not even being judged for his actual offense, the self-defensive murder of an Arab, but for the impression he made on the elderly residents during his mother's burial. As the elderly take the stand against Meursault, it is clear that their collective opinion has been shaped and molded by the administrative cadre, providing yet another example of how the urge to concur with a dominant opinion clouds objectivity. When Meursault left Marengo, the elders felt intimately drawn to him ("En sortant, et à mon grand étonnement, ils m'ont tous serré la main - comme si cette nuit où nous n'avions pas échangé un mot avait accru notre intimité" [p. 1131]). Yet at the trial, they provide evidence of his cold-heartedness, a perception that is more the result of subjective manipulation that objective fact.

Just as the trial recalls Meursault's visit to the home and vigil over the body, there are a number of parallels linking the prison-like setting of the home in Part 1 to the actual prison wherein Meursault awaits his execution in Part 2. In both, involuntary inmates await an imminent rendez-vous with death; both the home and the prison maintain order through the establishment and enforcement of stringent rules. Linguistic cacophony, loss of identity, isolation, and the omnipresent reality of life being extinguished characterize the two environments. In both the home and the prison, the inmates ponder an imposed death sentence that is perceived by others to be the logical outcome of events. The elderly, deemed expendable by the outside world, are forcibly removed from society, and left to die at the edge of consciousness, out of sight and therefore out of mind. Meursault's initial impression of the elderly confirms their status as social pariahs whose fate it is to fade away in exiled obscurity. Meursault admits to having rarely visited his mother:

C'est un peu pour cela que dans la dernière année je n'y suis presque plus allé. Et aussi parce que cela me prenait mon dimanche

11 For MAKARI, G. J. The Last Four Shots: Problems of Intention and Camus' The Stranger. American Imago: Studies in Psychoanalysis \& Culture, n. 45, ano 4, p. 367, 1988; the last shots reflect not only a desire for self-mastery, but for self-punishment. See also the article by GAY-CROSIER, R. Une étrangeté peu commune: Camus et Robbe-Grillet. Revue des Lettres Modernes, n. 16, p. 149-165, 1995. 
- sans compter l'effort pour aller à l'autobus, prendre des tickets et faire deux heures de route. (p. 1126)

In death, he refuses yet to acknowledge her. The general reluctance to confront directly the blighted existence of those designated as "outsiders" can be seen during Meursault's trial as well. The reporter who stared at him so intently during the trial suddenly averts his gaze when the guilty verdict and sentence is read.

Many critics have also pointed out the narrative resemblances linking the burial of Meursault's mother, the murder on the beach, and Meursault's final thoughts in prison. ${ }^{12}$ All three episodes reveal the structures of depersonalization that are essential elements for the marginalization of undesirables. At the home, the inmates have become indistinguishable from one another as a result of their regimented behavior; the unnamed Arabs are depicted as subhuman beings and are often compared to reptiles or stones; during the trial, Meursault is barred from speaking on his own behalf; in prison his reflected image seems unfamiliar, as does the sound of his own voice ("Je l'ai reconnue [sa voix] pour celle qui résonnait déjà depuis de longs jours à mes oreilles et j'ai compris que pendant tout ce temps j'avais parlé seul" [p. 1181]). These three primary episodes of the novel also demonstrate persuasively how the act of being ostracized tautologically confirms its own legitimization. The corrosive power of group allegiance buries impartiality beneath a consensus of culpability. In order to legitimize their surrender to group pressure, the convicting masses can take comfort only by linking the act of marginalization with villainy, by blaming the victim for his own vulnerability. This self-delusional rationalization allows the accusers to self-exculpate, and thereby cover the traces of their moral capitulation. ${ }^{13}$ The outcasts are ceremoniously removed from society: the elderly are sent to die in distant rest homes; the anonymous Arabs appear and disappear without warning; Meursault takes his place on death row. Once alienated from the majority, the victims, guilty by reason of marginalization, are of no further consequence. ${ }^{14}$

12 See for example, the observations of SCHOFER, P. The Rhetoric of the Text: Causality, Metaphor and Irony. In: KING, A. (Ed.). Camus's L'Étranger: Fifty Years On. New York: St. Martin's Press, 1992. p. 147-149. 
The successful demonization of Meursault ensures his execution, much like Raymond's discrediting of the Arab provoked Meursault to assassinate him. In both cases, prevailing prejudices are used to consolidate random and inconclusive fragments of existence in order to isolate, and thereby, communally condemn, an innocent man. In the case of Meursault, once his inhumanity is placed in evidence, a contagion of contempt prevails over evidentiary insufficiency (' $j$ ' ai eu une envie stupide de pleurer parce que j'ai senti combien j'étais détesté par tous ces gens-là" [p. 1187]). Disgust legitimizes condemnation ("J'ai senti alors quelque chose qui soulevait toute la salle et, pour la première fois, j'ai compris que j'étais coupable" [p. 1187]), and Merusault is sentenced to death.

It bears noting that the trial's verdict actually constitutes Meursault's second formal conviction. The first verdict is recorded in the title, L'Étranger, and was supplied by an unseen, but presumably authoritative, figure whose assessment the reader is willing to accept on faith. Meursault's narrative is emptied of legitimacy from the very first sentence, even before the reader hears one word from Meursault. In order to justify the usurping narrator's opinion, the reader dutifully scrutinizes the text for evidence of Meursault's flaws. Not unlike the prosecutor who manipulates Meursault's ignorance of funeral protocols to condemn him, the reader fastens upon a few isolated remarks or minor eccentricities in an attempt to justify the titular condemnation. The reader's unblinking complicity with the ursurping narrator demonstrates how easily a dominant opinion can persuade, even in the absence of evidence or even truth. Although the reader is provided with a number of examples that could serve to refute the prevailing prejudice, he continues to read Meursault's account through the prism of the usurping narrator's biased opinion. We are persuaded by the title that the account we are about to consider is from the pen of a socially defective being. Meursault is therefore twice denied the possibility of an impartial hearing: first by the usurping narrator who prejudices the reader against him, and second, by the judges at trial. The reader's alliance with the usurping narrator in the absence of evidence makes him an accomplice in Meursault's victimization, and reveals him to be as morally culpable as those who actually condemn him. ${ }^{15}$

Most outsiders facilitate the legitimization process by accepting their imposed subordination, thereby becoming willing accomplices in their own demise. The elderly and the Arabs offer no real protest against their involuntary subordination. Meursault and his mother, on the other, constitute two exceptions

13 See SJURSEN (1995, p. 131).

14 SJURSEN (1995, p. 125), also links culpability with ostracism. 
to the rule. Both refuse to concede that their marginalized status is proof of culpability. Meursault's mother brazenly takes on a "fiancé" as if to start her life anew. Meursault' rebellion against his fate is initiated when the chaplain forces his way into Meursault's cell in order to extract the mea culpa that will confirm his guilt. What unleashes Meursault's cathartic fury is the Chaplain's presumption of superiority, his reference to Meursault as his unenlightened subordinate, and his pledge to pray for his unworthy soul. His patriarchal and patronizing attitude suggests that there is a link between condemnation and culpability, something Meursault knows to be false. Despite the chaplain's sanctimonious blather, he enjoys no more privileged status than does Meursault, and he therefore has no right to consider him his subordinate. The attempt to transform death into warranted punishment presumes that only the culpable will die, while the privileged will survive. The universe, however, offers no exemption for the innocent, leaving Meursault to conclude that the binary categories of privileged and unprivileged, moral and immoral, are but manufactured and arbitrary concepts. Because we are all mortal (and therefore under the same death sentence) we are all equal before the universe. The oppressed and the oppressor will alike fall victim to their fate. Those who sentence others to die will die one day in turn, nullifying the moral authority on which the executioners presume to act. ${ }^{16}$

When the chaplain leaves, Meursault is finally able to transform victimization into triumph, fearful apprehension of the future into joyful exaltation of the here and now. Like his mother, he will not acknowledge the legitimacy of the verdict condemning him, the link between marginalization and expendability. Merusault's mother chose to live her life as a condemned woman exactly as she lived prior to being exiled in the home. Meursault, too, is determined to regard his sentence as a coda rather than a finale. Indeed, for Meursault, alienation constitutes not punishment but deliverance. Freed finally from the need to please others, he regains exclusive domain over his thoughts and actions. His "crimes",

15 FLETCHER, J. L'Étranger and the New Novel. In: KING, A. (Ed.). Camus's L'Étranger: Fifty Years On. New York: St. Martin's Press, 1992, p. 213; offers a more forgiving portrait of the reader. In his assessment, Meursault is actually acquitted by his readers, leading to his final triumph over injustice. HUNWICK, A. Albert Camus, Meursault, et le lecteur "dupe". La Revue des Lettres Modernes, n. 1123-1132, p. 167, 1993; also believes the reader is more interested in defending than condemning Meursault. [C/ AUTOR: confirmar n. e p.]

16 "The injustice visited upon Meursault by the court is an image of that which is inflicted on all human beings by virtue of their moral condition: the death sentence which is imposed on each and every one of us seems as arbitrary and unjust as that to which Meursault falls victim." (notes: HARGREAVES, A. G. History and Ethnicity in the Reception of L'Étranger. In: KING, A. (Ed.). Camus's L'Étranger: Fifty Years On. New York: St. Martin's Press, 1992. p. 108-109). 
after all, were all the result of communal pressure. He killed the Arab from a sense of allegiance to Raymond and the desire to belong; he was condemned because the prosecutor was able to successfully transform his funerial detachment into active villainy in the eyes of the jury. Communal opinion, then, is responsible for at least two deaths in the novel (the Arab's and Meursault's), and it is therefore with a sense of principle that Meursault now embraces his outsider status.

Those who capitulate to prevailing prejudices are the real prisoners, those who cling to the false hope that the execution of others will somehow bring them personal redemption. But as Meursault's father and even Meursault himself experienced, the willful execution of another is accompanied only by nauseating metaphysical silence. In the wake of Meursault's crucifiction, the accusing mob will find no redemption, only the palpable certainty of human loss, a foreshadowing of the death that awaits all, guilty or otherwise. Meursault's intellectual purity restored (“Comme si cette grande colère m'avait purgé du mal, vidé d'espoir, devant cette nuit chargée d'étoiles, je m'ouvrais pour la première fois à la tendre indifférence du monde"[p. 1209]), he is now able to fully savor the few precious moments remaining. The universe in a sense has granted his appeal and exculpated him from blame. As he draws his final breath, Meursault will find some measure of comfort in the enmity of his accusers who will attempt once again to re-define and reconstruct him in their own contrived image. Ironically, their presence confirms the failure of existential aspirations. As it turns out, man cannot define himself by his actions; he is always ill-defined by the consensus of others. Meursault's attempt to claim responsibility for the murder of the Arab was all for naught. He was condemned not for his act, but for the impression he made as a "foreign" presence in the home at Marengo. Consequently, in defiance of existentialist theory, Merusault's foreign "essence" triumphed over existence, that is to say, the documented record of lived experience. The Meursault the crowd executes is not the Meursault who narrates his story. But as Meursault prepares to become one with the universe, he goes forward with the lucid awareness that at least one existential tenet remains intact. The "mauvaise foi" of his executioners allows them to remain fervently committed to their delusions of morality. But their attempt to alchemize indiscriminate slaughter into moral necessity (and thereby exorcize communal demons by proxy) attests not to the glory of principled commitment, but only to man's pathetic, yet apparently abiding, need to surrender to the psychic pressure of communal error. 


\begin{abstract}
For many readers, Camus' L'Etranger traces the protagonist's evolution from a state of self-indulgent unawareness to one of metaphysical lucidity. This article exposes the shortcomings of such readings by focusing rather on Meursault's fundamentally static nature. In fact, this infamous character's intellectual perspective and situational reality remain virtually unchanged from beginning to end. The sole evolution in evidence is in the "vision" of others, who fall prey to the prevailing prejudices of a dominant group. In consequence, an unremarkable but well-liked man is transformed into a social pariah via a tidal wave of condemnation - while the man himself is unchanged, victimized by conceptual deformations that are imposed upon him. The anti-hero's status as an outsider signals, then, not merely the force of public opinion, but the flawed nature of the existentialist endeavor (a movement from which Camus wished ostensibly to be disassociated). The novel comes to represent, not the phenomenon of auto-determined or self-altered identity, but the unstable contingencies imposed from without and from which there is no exit.

Key-words: Camus, The Stranger (L'Etranger), existentialism, modern fiction, stasis.
\end{abstract}

\title{
WORKS CITED
}

BARNETT, R- L. Le simulacre inaugural: Micro-lecture camusienne. Symposium, ano 3, n. 53, p. 59-69, 1999.

. The Trope Disfigured: Effacement and Epidemicity in Camus' La Peste. Rivista

di Letterature moderne e comparate, ano 3, n. 54, p. 307-320, 2001.

BARTFELD, F. Aspects du destin dans L'Étranger. Hebrew University Studies in Literature \& the Arts, ano 2, n. 9, p. 291-315, 1981.

BROCK, R. Meursault the Straw Man. Studies in the Novel, ano 1, n. 25, p. 92-100, 1993.

CAMUS, A. Théâtre, Récits, Nouvelles. Paris: Pléiade, 1962.

CHAMPIGNY, R. Sur un héros païen. Paris: Gallimard, 1959.

CHATAIN, G. D. Narrative Desire. In: KING'A. (Ed.). L'Étranger. Camus 's L'Étranger: Fifty Years On. New York: St. Martin's Press, 1992. p. 125-137. 
MURATORE, M. J. Distanced by default or the mandates...

FLETCHER, J. L'Étranger and the New Novel. In: KING, A. (Ed.). Camus's L'Étranger: Fifty Years On. New York: St. Martin's Press, 1992. p. 209-220.

GAY-CROSIER, R. Une Étrangeté peu commune: Camus et Robbe-Grillet. Revue des Lettres Modernes, n.16, p. 149-165, 1995.

GRÉGOIRE, V. Monde "sourd"-Monde "absurde" ou Pour une impossibilité de s'entendre dans L'Étranger. Romanic Review, ano 3, n. 85, p. 403-418, 1994.

HARGREAVES, A. G. History and Ethnicity in the Reception of L'Étranger. In: KING, A. (Ed.). Camus's L'Étranger: Fifty Years On. New York: St. Martin's Press, 1992. p. 101112.

HUNWICK, A. Albert Camus, Meursault, et le lecteur “dupe". La Revue des Lettres Modernes, n. 1123-1132, p. 153-179, 1993. [C/AUTOR: confirmar número e página]

MAKARI, G. J. The Last Four Shots: Problems of Intention and Camus' The Stranger. American Imago: Studies in Psychoanalysis \& Culture, ano 4, n. 45, p. 359-374, 1988.

MISTACCO, V. Mama's Boy: Reading Woman in L'Etranger. In: KING, A. (Ed.). Camus's L'Étranger: Fifty Years On. New York: St. Martin's Press, 1992. p. 152-169.

MOROT-SIR, E. Actualité de L'Étranger. Revue des Lettres Modernes, n. 17, p. 7-26, 1996.

RIGGS, L.; WILLOQUET-MARICONDI, P. Colonialism, Enlightement, Castration: Writing, Narration, and Legibility in L'Étranger. Studies in Twentieth Century Literature, ano 2, n. 16, p. 265-288, 1992.

SCHOFER, P. The Rhetoric of the Text: Causality, Metaphor and Irony. In: KING, A. (Ed.). Camus's L'Étranger: Fifty Years On. New York: St. Martin's Press, 1992. p. 147149.

SJURSEN, N. Meursault, Un Job de Notre Temps? Une Lecture Girardienne. Revue des Lettres Modernes, n. 16, p. 123-135, 1995. 